\title{
Characterisation of the non-starter lactic acid bacteria (NSLAB) of Gruyère PDO cheese
}

\author{
Michael G. CASEY, Jean Pierre HÄNI, Josef GRUSKOVNJAK, \\ Walter SCHAEREN, Daniel WECHSLER* \\ Agroscope Liebefeld-Posieux Research Station ALP, Schwarzenburgstrasse 161, \\ 3003 Berne, Switzerland
}

Received 13 April 2006 - Accepted 18 October 2006

\begin{abstract}
The diversity of non-starter lactic acid bacteria (NSLAB) of Swiss Gruyère cheese was studied in three factories over a six-month period. A total of 1099 isolates of NSLAB from raw milk, skimmilk and Gruyère cheese were characterised at both the species and strain level. Over $90 \%$ of the isolates were either Lactobacillus casei or L. rhamnosus, and a combined total of 45 genotypes were found. The genotypes from the three factories differed from one another and varied slowly over the six-month period. At one factory, samples from the corresponding raw milk, skimmilk and cheese culture were also analysed. No NSLAB were found in the cheese starter culture. On the contrary, raw milk contained the largest number of different genotypes. The genotypes found in the cheese all came from raw milk.
\end{abstract}

non-starter lactic acid bacteria / NSLAB / L. casei / L. rhamnosus / Gruyère cheese

摘要 - 原产地命名保护的 Gruyère 干酪中非发酵剂乳酸菌的特性研究。系统地研究了由 3 个工厂生产的瑞士 Gruyère 干酪在 6 个月成熟期内非发酵剂乳酸菌 (NSLAB) 的生物多样性。 从原料奶、脱脂乳和 Gruyère 干酪中共分离出 1099 株非发酵剂乳酸菌, 这些菌株均鉴定到 种和株。90\% 以上的分离菌株属于干酪乳杆菌 (Lactobacillus casei) 和鼠李糖乳杆菌 (L. rhamnosus), 分属于 45 个基因类型。从 3 个工厂生产的干酪中得到乳酸菌的基因类型互 不相同, 并且在 6 个月成熟内这些乳酸菌的变化非常缓慢。对其中一个工厂生产的干酪及 其所用的原料奶、脱脂乳和发酵剂进行了详细地分析, 在发酵剂的培养物中没有发现非发 酵剂乳酸菌，相反在原料奶中则发现了许多不同基因类型的乳酸菌。在干酪中所分离的非 发酵剂乳酸菌的基因类型几乎全部来源于原料奶。

非发酵剂乳酸菌 (NSLAB) / Gruyère 干酪 / 干酪乳杆菌 / 鼠李糖乳杆菌 / 干酪

Résumé - Caractérisation des bactéries lactiques non levain (NSLAB) du Gruyère AOC. La diversité des bactéries lactiques non levain (NSLAB) du Gruyère suisse a été étudiée sur une période de 6 mois dans trois fromageries. Au total, 1099 isolats de NSLAB provenant de lait cru, de lait écrémé et de Gruyère ont été caractérisés au niveau de l'espèce et de la souche. Plus de $90 \%$ des isolats étaient issus soit de Lactobacillus casei, soit de L. rhamnosus. Parmi ces isolats, on a trouvé un total de 45 génotypes différents. Les génotypes identifiés dans les trois fromageries différaient les uns des autres et variaient faiblement au cours des 6 mois. En outre, dans une fromagerie, des échantillons de lait cru, de lait écrémé et de fromage tous issus de la même matière première ont été analysés. Aucun NSLAB n'a été trouvé dans le levain traditionnel de fromagerie. Par contre, le lait cru contenait le nombre le plus important de génotypes différents. Les génotypes trouvés dans le fromage provenaient tous du lait cru.

bactéries lactiques non levain / NSLAB / L. casei / L. rhamnosus / Gruyère suisse

* Corresponding author (通讯作者): daniel.wechsler@alp.admin.ch 


\section{INTRODUCTION}

Non-starter lactic acid bacteria (NSLAB) are defined as lactic acid bacteria found in cheese which do not form part of the starter culture and consist of four main groups of bacteria, i.e. mesophilic lactobacilli, pediococci, enterococci and Leuconostoc. All natural cheeses studied to date contain bacteria from at least one of these four groups. Among the mesophilic lactobacilli, members of the facultatively heterofermentative lactobacilli are most often encountered in cheese. There appears to be some variation in NSLAB depending on the cheese variety, processing and duration of ripening [2]. In a range of cheeses such as Cheddar of different origins, Fiore Sardo, Fossa cheese and other European traditional cheeses, L. casei, L. plantarum, $L$. curvatus and L. rhamnosus were the dominant species of the mesophilic lactobacillus flora, but also various other species occurred at lower levels $[3,8,11,12,14,16$, 21]. Raw milk is the main source of the NSLAB, but also other sources such as other cheese-making ingredients and contamination of plant equipment with persistent biofilms contribute to the NSLAB composition. Although pasteurisation reduces the flora of the raw milk to a large extent, small numbers of mesophilic lactobacilli may survive and subsequently grow in cheese made from pasteurised milk. Mesophilic lactobacilli grow in cheese to levels of $10^{6}-10^{8} \mathrm{cfu} \cdot \mathrm{g}^{-1}$ over the first $10-$ 20 weeks of ripening and remain at high concentrations until the end of the ripening period $[2,18,19]$. Comparison of cheeses made from raw milk with those made from microfiltered or pasteurised milk has shown that the raw milk flora plays an essential role in the development of the sensory characteristics of hard cheeses. In most cases it was found that elimination of the raw milk flora leads to a less intense cheese flavour $[6,10,17]$. Several studies further indicated that mesophilic adjuncts can exert a positive effect on flavour [5, 8, 19]. However, it remains difficult to quantify the impact of individual strains of NSLAB on cheese quality since it is impossible to achieve complete control of cheese flora. In order to better understand the role played by this microflora in the development of the sensory characteristics of cheese, it is necessary to identify them not only at the species level but eventually at the strain level using electrophoretic techniques such as pulsed-field gel electrophoresis, hybridisation techniques and PCR-based methods.

Until now, the description of the ecosystem of raw milk and Gruyère cheese has been based on classical microbiological methods which are limited to describing bacteria at the species or sub-species level. Analysis of this microflora using modern molecular biology methods should provide us with further knowledge of these strains as well as their origin, diversity and variability.

Three different cheese factories, that consistently produced Gruyère cheese of high quality, were selected and the diversity of NSLAB of six-month-old cheeses produced at monthly intervals over a period of six months was analysed.

\section{MATERIALS AND METHODS}

\subsection{Manufacture of Gruyère PDO cheese}

The present investigation on NSLAB in Swiss Gruyère cheese was performed in collaboration with three typical factories located in Pomy (approval number $\mathrm{CH}$ 4418), Mezieres (CH-4089) and La Brévine $(\mathrm{CH}-4214)$ during the period of August 2002 until January 2003. Traditional Gruyère $\mathrm{PDO}$ cheese was produced according to the list of requirements of the Gruyère association. Briefly, the fat content of the cheese milk was adjusted by adding skimmed raw milk to the untreated raw milk. The cheese milk was warmed in a copper vessel to $30-32{ }^{\circ} \mathrm{C}$, inoculated with $1 \%$ o ( $\mathrm{vol} / \mathrm{vol}$ ) traditional whey culture and coagulated with calf rennet in approximately $35-50 \mathrm{~min}$. The curd was cut into grains of about $0.3 \mathrm{~cm}$ and cooked to $56-58{ }^{\circ} \mathrm{C}$ for $35-45 \mathrm{~min}$. The curd was poured into moulds and after pressing kept at room temperature. Once the $\mathrm{pH}$ reached 5.2, the cheeses were salted in brine for $24 \mathrm{~h}$. For the first 10 days of ripening the cheeses were salted and smeared daily, then cured and 
ripened at about $14{ }^{\circ} \mathrm{C}$ until the age of six months.

\subsection{Sampling of the study materials}

In order to study the influence of raw milk, processing equipment and starter cultures on NSLAB composition, samples of raw milk, skimmed milk and traditional whey cultures were taken at monthly intervals over a period of six months from each factory and stored at $-80{ }^{\circ} \mathrm{C}$ until used for analysis. The corresponding cheese samples were collected after a ripening period of six months.

\subsection{Isolation of bacteria and growth conditions}

Bacteria were isolated from cheese by adding $10 \mathrm{~g}$ of grated cheese to $90 \mathrm{~mL}$ peptone water, heating for $10 \mathrm{~min}$ at $45^{\circ} \mathrm{C}$ and then plating out the diluted suspension on facultatively heterofermentative agar (FHagar) plates, since this media is specific for facultatively heterofermentative lactobacilli [13]. Furthermore, in a preliminary experiment the suspensions were plated out on lithium propionate agar (LP-agar) [15] in order to determine whether other bacterial species grew in the cheese. Since over $90 \%$ of the species were facultatively heterofermentative lactobacilli, it was decided to concentrate on this group for the main study. Fifty colonies were selected at random; the isolates were purified by plating out on MRS-agar three times and further cultured in MRS broth. Bacteria from milk and skimmilk were isolated after heat-treatment similar to manufacturing conditions by heating $10 \mathrm{~mL}$ at $57^{\circ} \mathrm{C}$ for $6 \mathrm{~min}$ and then directly plating out on $\mathrm{FH}$-agar. Without this heat-treatment other types of bacteria, such as Weisella, Leuconostoc and Pediococci, grew on the agar plates. One hundred and thirty-four bacterial colonies were isolated from milk and 65 from skimmilk.

\subsection{Total DNA preparation}

Genomic DNA was prepared from $1 \mathrm{~mL}$ of a stationary phase culture as described previously [7].

\subsection{Species identification}

The 16S rRNA gene was amplified by PCR with the primers bak11w (5'-AGTTTGATCMTGGCTCAG-3') and Univ-518 (5'-CWATTACCGCGGCKGCTG-3') [9]. The PCR products were purified using the QIAquick PCR Purification Kit and sequenced using the same primers on an ABI Prism ${ }^{\circledR} 310$ Genetic Analyser using the BigDye Terminator Cycle sequencing kit. Each species was identified by comparing the DNA sequence obtained with those in the NCBI database.

\subsection{Strain identification}

Isolated strains were grouped into genotypes by repetitive sequence-based polymerase chain reaction (REP-PCR) which was performed on DNA extracts using the primer GTG5 (5'-GTGGTGGTGGTGGTG-3') as described previously [20].

\section{RESULTS}

\subsection{Cheese}

In a series of preliminary experiments cheese extracts were plated out on LP-agar. Thermophilic cheese starters did not produce colonies on this agar, thus making it suitable for studying the NSLAB content of cheese. One hundred isolates each from the three cheese factories were identified at the species level by DNA sequencing of $16 \mathrm{~S}$ rRNA. The different groups found are listed in Table I. Over $90 \%$ of the bacteria found were facultatively heterofermentative lactobacilli. This confirms the results found with other cheese types $[1,8,14,16]$ and indicates that these mesophilic lactobacilli can contribute to the flavour of Gruyère cheese.

Fifty randomly selected isolates from each cheese sample were identified by DNA sequencing of the $16 \mathrm{~S}$ rRNA. The results of the identification are given in Table II. The bacteria were found at concentrations between $10^{6}$ and $10^{7} \mathrm{cfu} \cdot \mathrm{g}^{-1}$ and the large majority of isolates were Lactobacillus casei. 
Table I. Bacterial groups found in cheese extracts after growth on lithium propionate agar (100 isolates from each factory were analysed).

\begin{tabular}{lccc}
\hline Group / Species & $\begin{array}{c}\text { Factory } \\
\text { CH-4089 }\end{array}$ & $\begin{array}{c}\text { Factory } \\
\text { CH-4214 }\end{array}$ & $\begin{array}{c}\text { Factory } \\
\text { CH-4418 }\end{array}$ \\
\hline Facultative heterofermentatively lactobacilli & & & \\
$\quad$ L. casei & 100 & 32 & 58 \\
$\quad$ L. rhamnosus & & 57 & 40 \\
Pediococci & & 9 & \\
Enterococci & 1 & 2 \\
\hline
\end{tabular}

Table II. Concentrations and percentages of facultatively heterofermentative lactobacilli in Gruyère cheeses after six months of ripening (50 randomly selected isolates from each factory and each month).

\begin{tabular}{|c|c|c|c|c|c|c|}
\hline \multirow[t]{2}{*}{ Month } & \multicolumn{2}{|c|}{ Cheese Factory CH-4214 } & \multicolumn{2}{|c|}{ Cheese Factory CH-4418 } & \multicolumn{2}{|c|}{ Cheese Factory CH-4089 } \\
\hline & $10^{6} \mathrm{cfu} \cdot \mathrm{g}^{-1}$ & $\%$ & $10^{6} \mathrm{cfu} \cdot \mathrm{g}^{-1}$ & $\%$ & $10^{6} \mathrm{cfu} \cdot \mathrm{g}^{-1}$ & $\%$ \\
\hline August & 6 & $\begin{array}{l}88 \% \text { L. casei } \\
12 \% \text { L. rhamnosus }\end{array}$ & 2 & $100 \%$ L. casei & 3 & $100 \%$ L. casei \\
\hline September & 2 & $\begin{array}{l}81 \% \text { L. casei } \\
19 \% \text { L. rhamnosus }\end{array}$ & 8 & $100 \%$ L. casei & 1 & $100 \%$ L. casei \\
\hline October & 10 & $100 \%$ L. casei & 1 & $\begin{array}{l}82 \% \text { L. casei } \\
18 \% \text { L. rhamnosus }\end{array}$ & 6 & $100 \%$ L. casei \\
\hline November & 8 & $\begin{array}{l}58 \% \text { L. casei } \\
42 \% \text { L. rhamnosus }\end{array}$ & 5 & $100 \%$ L. casei & 4 & $100 \%$ L. casei \\
\hline December & 6 & $100 \%$ L. casei & 3 & $100 \%$ L. casei & 2 & $100 \%$ L. casei \\
\hline January & 2 & $100 \%$ L. casei & 0.7 & $100 \%$ L. casei & 2 & $100 \%$ L. casei \\
\hline
\end{tabular}

The different isolates were then analysed by REP-PCR in order to evaluate the different genotypes present.

A combined total of 45 different genotypes were found in the cheeses from the three cheese factories over the six-month period. The genotypes from the three cheese factories were all different from one another. The distribution of the genotypes over the six-month period is shown in Tables III-V.

\subsection{Milk and skimmilk}

In order to determine the origin of the facultatively heterofermentative lactobacilli we examined the raw milk and skimmilk, used for the manufacture of cheese, for the presence of these bacteria. The Jan- uary milk samples from cheese factory $\mathrm{CH}$ 4214 were chosen as an example, since the cheese made by it contained only the three genotypes $\mathrm{C} 32, \mathrm{C} 44$ and $\mathrm{C} 45$ at relatively equal concentrations (Tab. V). Fourteen different genotypes of NSLAB were found in raw milk, whereas only 4 genotypes were found in skimmilk (Tab. VI). All three genotypes present in cheese as well as 3 of the genotypes present in skimmilk were also found in the corresponding raw milk samples. The genotypes and frequency of facultatively heterofermentative lactobacilli found in raw milk, skimmilk and cheese are summarised in Table VI.

\subsection{Starter cultures}

The traditional whey culture used for the manufacture of cheese in factory $\mathrm{CH}-4214$ 
Table III. Numbers of facultatively heterofermentative lactobacilli isolates of different genotypes found in Gruyère cheeses after six months of ripening in cheese factory $\mathrm{CH}-4089$ over a period of six months (50 randomly selected isolates from one cheese each month identified).

\begin{tabular}{lcccccc}
\hline Genotype & Aug & Sep & Oct & Nov & Dec & Jan \\
\hline C1 & 34 & 34 & 6 & 21 & 42 & 41 \\
C2 & 9 & 3 & & & & 3 \\
C3 & 7 & 3 & 2 & 6 & & \\
C4 & & 10 & & & & \\
C5 & & & 42 & & & \\
C6 & & & & 22 & & \\
C7 & & & & 1 & & \\
C8 & & & & & 8 & \\
C9 & & & & & & 6 \\
\hline
\end{tabular}

Table IV. Numbers of facultatively heterofermentative lactobacilli isolates of different genotypes found in Gruyère cheeses after six months of ripening in cheese factory $\mathrm{CH}-4418$ over a period of six months (50 randomly selected isolates from one cheese each month identified).

\begin{tabular}{lcccccc}
\hline Genotype & Aug & Sep & Oct & Nov & Dec & Jan \\
\hline C10 & 46 & 16 & & & & \\
C11 & 2 & 1 & & & 3 & \\
C12 & 2 & 21 & 31 & & & \\
C13 & & 7 & & 50 & & \\
C14 & & 3 & & & & \\
C15 & & 1 & & & & \\
C16 & & & 5 & & & \\
C17 & & & 5 & & 21 & \\
C18 & & & 9 & & 2 & \\
C19 & & & & & 5 & \\
C20 & & & & 7 & \\
C21 & & & & 8 & \\
C22 & & & & 3 & \\
C23 & & & & 1 & \\
C24 & & & & & & 50 \\
\hline
\end{tabular}

in January did not contain any facultatively heterofermentative lactobacilli detectable by our method.
Table V. Numbers of facultatively heterofermentative lactobacilli isolates of different genotypes found in Gruyère cheeses after six months of ripening in cheese factory $\mathrm{CH}-4214$ over a period of six months (50 randomly selected isolates from one cheese each month identified).

\begin{tabular}{lcccccc}
\hline Genotype & Aug & Sep & Oct & Nov & Dec & Jan \\
\hline C25 & 7 & 1 & & & & \\
C26 & 7 & & & & & \\
C27 & 21 & & & 1 & & \\
C28 & 3 & 6 & & 7 & & \\
C29 & 1 & & & & & \\
C30 & 1 & & & & 8 & \\
C31 & 7 & 1 & 2 & & 1 & \\
C32 & 3 & & & & & 10 \\
C33 & & 23 & 16 & 4 & & \\
C34 & & 18 & 28 & 36 & & \\
C35 & & 1 & 1 & & & \\
C36 & & & 3 & 1 & & \\
C37 & & & & 1 & & \\
C38 & & & & & 29 & \\
C39 & & & & & 3 & \\
C40 & & & & & 2 & \\
C41 & & & & & 1 & \\
C42 & & & & & 3 & \\
C43 & & & & & 3 & \\
C44 & & & & & & 27 \\
C45 & & & & & & 13 \\
\hline
\end{tabular}

\section{DISCUSSION}

In the present study a total of 1099 isolates of NSLAB from cheese milk, skimmilk and Gruyère cheese from three different cheese factories were identified at the species and genotype levels. Previously, Berthier et al. [4] described the diversity of mesophilic lactobacilli in Comté cheese, which has often been compared with Gruyère cheese. Whereas the study with Comté cheese concentrated on the development of mesophilic lactobacilli during ripening, our study examined six-month-old cheeses produced at monthly intervals over a period of six months. 
Table VI. Genotypes of facultatively heterofermentative lactobacilli and their frequency found in cheese milk, skimmilk and the corresponding six-month-old cheese of the January production in factory CH-4214 (RM1-RM14 = genotypes isolated from raw milk, SM1-SM4 = genotypes isolated from skimmilk, C1-C45 = genotypes isolated from cheese).

\begin{tabular}{|c|c|c|c|c|c|}
\hline & Genotype & & $\begin{array}{l}\text { Raw milk } \\
(\mathrm{n}=134)\end{array}$ & $\begin{array}{l}\text { Skimmilk } \\
(\mathrm{n}=65)\end{array}$ & $\begin{array}{l}\text { Cheese } \\
(n=50)\end{array}$ \\
\hline RM1 & = SM1 & \multirow[t]{3}{*}{$=\mathrm{C} 44$} & 3 & 42 & \multirow[t]{3}{*}{27} \\
\hline RM2 & $=\mathrm{SM} 2$ & & 1 & 16 & \\
\hline RM3 & & & 112 & & \\
\hline RM4 & & \multirow[t]{4}{*}{$=\mathrm{C} 45$} & 1 & & \multirow[t]{4}{*}{13} \\
\hline RM5 & & & 2 & & \\
\hline RM6 & & & 2 & & \\
\hline RM7 & & & 1 & & \\
\hline RM8 & & \multirow[t]{4}{*}{$=\mathrm{C} 32$} & 4 & & \multirow[t]{4}{*}{10} \\
\hline RM9 & & & 1 & & \\
\hline RM10 & & & 1 & & \\
\hline RM11 & & & 2 & & \\
\hline RM12 & \multirow[t]{3}{*}{$=\mathrm{SM} 3$} & & 1 & \multirow[t]{3}{*}{6} & \\
\hline RM13 & & & 2 & & \\
\hline RM14 & & & 1 & & \\
\hline & SM4 & & & 1 & \\
\hline
\end{tabular}

Similarly to us, Berthier et al. [4] found that over $90 \%$ of the NSLAB isolates from the mature cheeses belonged to the species of L. casei or L. rhamnosus and were present at concentrations of $10^{6}-10^{7} \mathrm{cfu} \cdot \mathrm{g}^{-1}$ cheese after six months of ripening. We found between 1 and 8 genotypes per cheese, which is also similar to Comté. The genotypes from the three Gruyère cheese factories were different from one another, which is not surprising since the factories are situated at least $50 \mathrm{~km}$ apart.

The genotypes of the NSLAB in Gruyère cheese within each factory varied over time, but generally there was an overlap in the genotypes from one month to another. However, the shifts in the genotypes in the cheeses of the three factories were different from one another. The dominant genotype in the cheeses from factory $\mathrm{CH}-4089$ was present over the whole six-month period, whereas the dominant genotype in cheeses from factory $\mathrm{CH}-4418$ changed slowly with time and was completely different after six months. The cheeses from factory $\mathrm{CH}-4214$ were in-between the two, since one of the genotypes found at the beginning of the study was still present after six months, even if it was no longer the dominant genotype. Since we reasoned that the cheese milk would be partially contaminated with NSLAB originating from the factory equipment and starter culture, we also analysed the skimmilk and starter culture from the same day as the cheeses were produced. In contrast to Comté cheese, the culture used for the manufacture of Gruyère cheese did not contain any NSLAB at a detectable level. This is possibly because during the preparation of the cultures for Gruyère the whey undergoes a preheating step at $59{ }^{\circ} \mathrm{C}$ before incubation at $38{ }^{\circ} \mathrm{C}$. Pretreatment at $59{ }^{\circ} \mathrm{C}$ eliminates a lot of bacteria. This procedure is not undertaken during the manufacture of Comté cheese.

Raw milk was found to be far richer than skimmilk in the number of genotypes of NSLAB that it contained (Tab. VI). This is not surprising, since skimmilk was prepared in the factories early in the morning from 
individual milks of the first delivering farmers and not from the combined raw milk of all suppliers. Of the four genotypes found in skimmilk only one was different from those found in raw milk.

The three genotypes found in the cheese were also found in raw milk, thus indicating that it is the raw milk flora and not the factory environment that principally determines the composition of the NSLAB in Gruyère cheese. Similarly to us, Crow et al. [8] observed a seasonal variation in NSLAB in New Zealand Cheddar cheese manufactured in 6 factories at different times, showing that the flora of the factory equipment did not lead to a persistent NSLAB composition in the cheese. It is interesting to note that in the cheese we could not find the dominant genotype in raw milk, but genotypes found at much lower concentrations. It can be assumed that some genotypes did not survive the temperatures applied during the cheese-making process.

\section{CONCLUSION}

In conclusion, the present study has shown that NSLAB in Swiss Gruyère mainly derive from raw milk and that generally only a few strains survive the processing conditions and grow during ripening. In addition, the study has shown that there is a continuous shift in the NSLAB composition in the ripened cheese over time. If individual strains of NSLAB were responsible for specific aroma development in Gruyère cheese this would imply that the aroma of cheeses from factory $\mathrm{CH}$ 4089 should not vary much over time, whereas cheeses from factory $\mathrm{CH}-4418$ would vary from month to month. Since the three investigated factories produced at a constant high quality level, it seems therefore unlikely that any individual strains of NSLAB have a dominant impact on flavour development of Swiss Gruyère cheese. However, further studies are necessary to elucidate the impact of NSLAB on the ripening ability and sensorial properties of this well-known PDO cheese.

\section{REFERENCES}

[1] Baruzzi F., Morea M., Matarante A., Cocconcelli P.S., Changes in the Lactobacillus community during Ricotta forte cheese natural fermentation, J. Appl. Microbiol. 89 (2000) 807-814.

[2] Beresford T.P., Non-starter lactic acid bacteria (NSLAB) and cheese quality, in: Smit G. (Ed.), Dairy processing - Improving quality, Woodhead Publishing Limited, Cambridge, England, 2003, pp. 448-469.

[3] Beresford T.P., Fitzsimons N.A., Brennan N.L., Cogan T.M., Recent advances in cheese microbiology, Int. Dairy J. 11 (2001) 259274.

[4] Berthier F., Beuvier E., Dasen A., Grappin R., Origin and diversity of mesophilic lactobacilli in Comté cheese, as revealed by PCR with repetitive and species-specific primers, Int. Dairy J. 11 (2001) 293-305.

[5] Beuvier E., Berthaud K., Cegarra S., Dasen A., Pochet S., Buchin S., Duboz G., Ripening and quality of Swiss-type cheese made from raw, pasteurized or microfiltered milk, Int. Dairy J. 7 (1997) 311-323.

[6] Bouton Y., Grappin R., Comparaison de la qualité de fromages à pâte pressée cuite fabriqués à partir de lait cru ou microfiltré, Lait 75 (1995) 31-44.

[7] Chavagnat F., Haueter M., Jimeno J., Casey M.G., Comparison of partial tuf gene sequences for the identification of lactobacilli, FEMS Microbiol. Lett. 217 (2002) 177-183.

[8] Crow V., Curry B., Hayes M., The ecology of non-starter lactic acid bacteria (NSLAB) and their use as adjuncts in New Zealand Cheddar, Int. Dairy J. 11 (2001) 275-283.

[9] Dasen G., Smutny J., Teuber M., Meile L., Classification and identification of Propionibacteria based on ribosomal RNA genes and PCR, Syst. Appl. Microbiol. 21 (1998) 251259.

[10] Demarigny Y., Beuvier E., Buchin S., Pochet S., Grappin R., Influence of raw milk microflora on the characteristics of Swiss-type cheeses: II. Biochemical and sensory characteristics, Lait 77 (1997) 151-167.

[11] Fitzsimons N.A., Cogan T.M., Condon S., Beresford T., Phenotypic and genotypic characterization of non-starter lactic acid bacteria in mature cheddar cheese, Appl. Environ. Microbiol. 65 (1999) 3418-3426.

[12] Gobbetti M., Folkertsma B., Fox P.F., Corsetti A., Smacchi E., De Angelis M., Rossi J., Kilcawley K., Cortini M., Microbiology and 
biochemistry of Fossa (pit) cheese, Int. Dairy J. 9 (1999) 763-773.

[13] Isolini D., Grand M., Glättli H., Selektivmedien zum Nachweis von obligat und fakultativ heterofermentativen Laktobazillen, Schweiz. Milchwirtschaft. Forsch. 19 (1990) 57-59.

[14] Jordan K.N., Cogan T.M., Identification and growth of non starter lactic acid bacteria in Irish Cheddar cheese, Ir. J. Agr. Food Res. 32 (1993) 47-55

[15] Lapierre L., Undeland P., Cox L.J., Lithium chloride-sodium propionate agar for the enumeration of bifidobacteria in fermented dairy products, J. Dairy Sci. 75 (1992) 1192-1196.

[16] Mannu L., Comunian R., Scintu M.F., Mesophilic lactobacilli in Fiore Sardo cheese: PCR-identification and evolution during cheese ripening, Int. Dairy J. 10 (2000) 383389.

[17] McSweeney P.L.H., Fox P.F., Lucey J.A., Jordan K.N., Cogan T.M., Contribution of the indigenous microflora to the maturation of Cheddar cheese, Int. Dairy J. 3 (1993) 613-634.
[18] Rehman S.U., Banks J.M., McSweeney P.L.H., Fox P.F., Effect of ripening temperature on the growth and significance of non-starter lactic acid bacteria in Cheddar cheese made from raw or pasteurised milk, Int. Dairy J. 10 (2000) 45-53.

[19] Rehman S.U., McSweeney P.L.H., Banks J.M., Brechany E.Y., Muir D.D., Fox P.F., Ripening of Cheddar cheese made from blends of raw and pasteurised milk, Int. Dairy J. 10 (2000) 33-44.

[20] Versalovic J., Schneider M., de Bruijn F.J., Lupski J.R., Genomic fingerprinting of bacteria using repetitive sequence based polymerase chain reaction, Method. Mol. Cell. Biol. 5 (1994) 25-40.

[21] Williams A.G., Banks J.M., Proteolytic and other hydrolytic enzyme activities in nonstarter lactic acid bacteria (NSLAB) isolated from Cheddar cheese manufactured in the United Kingdom, Int. Dairy J. 7 (1997) 763774 